\title{
Dobór elementów przekładnika ciśnienia i ich wplyw na parametry pracy
}

\begin{abstract}
$W$ artykule przedstawiono zakres stosowania przekładników ciśnienia dla poszczególnych pojazdów szynowych z rozbiciem na lokomotywy, wagony i jednostki trakcyjne. Przedstawiono opis przektadnika ciśnienia cylindrowego zaprojektowanego i wyprodukowanego przez Instytut Pojazdów Szynowych „TABOR”. Scharakteryzowano poszczególne elementy sktadowe jego budowy oraz wytypowano te, które maja istotny wptyw na zmianę parametrów pracy przektadnika ciśnienia. Przedstawiono aktualnie obowiqzujace kryteria dotyczqce parametrów działania przektadnika ciśnienia cylindrowego. Zaprezentowano wybrane wyniki badań, które polegały na ustaleniu wpływu parametrów sprężyny na zmiane wartości histerezy oraz poprawności działania przekładnika ciśnienia. Wartość histerezy oceniano bezwymiarowa wielkościq zwanq sprawnościq przektadnika, analizujac przebiegi ciśnień podczas hamowania i luzowania oraz stopniowego hamowania realizowanego przez przektadnik ciśnienia. W pracy zaprezentowano stanowisko do badań, na którym, przy pomocy mikroprocesorowego układu sterowania, zadawano odpowiednie przebiegi wartości ciśnień zgodnie z algorytmem sterowania stworzonym specjalnie do tego celu.
\end{abstract}

\section{WPROWADZENIE}

Podstawowym hamulcem stosowanym w kolejnictwie jest, wynaleziony jeszcze w XIX w. przez George'a Westinghouse'a, hamulec zespolony na sprężone powietrze (hamulec PN). Hamulec ten umożliwia maszyniście sterowanie hamowaniem lub luzowaniem wszystkich pojazdów wchodzących w skład pociagu połączonego z lokomotywą prowadzącą za pośrednictwem przewodu pneumatycznego zwanego przewodem głównym (PG). Funkcja hamulca PN wykonywana przez połączone $\mathrm{w}$ ten sposób układy hamulcowe lokomotywy i wagonów pociągu zależy od wartości i gradientu ciśnienia $\mathrm{w}$ przewodzie głównym określanych przez układ sterowania hamulcem PN zabudowany w lokomotywie. Za pomocą przewodu głównego maszynista przesyła sygnał sterowania hamowaniem do wszystkich pojazdów w pociągu: hamowanie następuje przez obniżenie ciśnienia powietrza w przewodzie głównym, natomiast luzowanie hamulców następuje poprzez jego zwiększenie. W jednostkach trakcyjnych hamowanie i luzowanie pojazdu może odbywać się także za pomocą hamulca elektropneumatycznego. Cały proces hamowania przebiegać może dzięki zastosowaniu elektrotechnicznego układu sterowania napełnianiem i opróżnianiem cylindrów hamulcowych lub też, jak to jest w przypadku nowoczesnych pojazdów, $\mathrm{z}$ wykorzystaniem sterowania mikroprocesorowego.
Aby cały system hamulcowy funkcjonował prawidłowo na każdym pojeździe, wchodzącym w skład pociagu, musi znajdować się odpowiednia aparatura odbierająca sygnały o hamowaniu bądź luzowaniu hamulców i ujednolicone do pewnego stopnia urządzenia wykonawcze w celu uzyskania zbliżonej skuteczności hamowania wszystkich wagonów w pociągu.

Dotyczy to najbardziej odpowiedzialnych urządzeń hamulcowych, takich jak zawór rozrządczy i przekładnik lub przekładniki ciśnienia cylindrów hamulcowych, przyspieszacz hamowania nagłego, zawór ważący i układ przeciwpoślizgowy [1].

\section{ZAKRES STOSOWANIA PRZEKLADNI- KÓW CIŚNIENIA}

Jednym z podstawowych modułów sterowania pneumatycznego w układzie hamulcowym są przekładniki ciśnienia. W Instytucie Pojazdów Szynowych „TABOR" opracowano rodzinę przekładników ciśnienia do napełniania cylindrów hamulcowych i przewodu głównego [2]. Przykładowe przekładniki ciśnienia pokazano na rys. 1 i 2. 

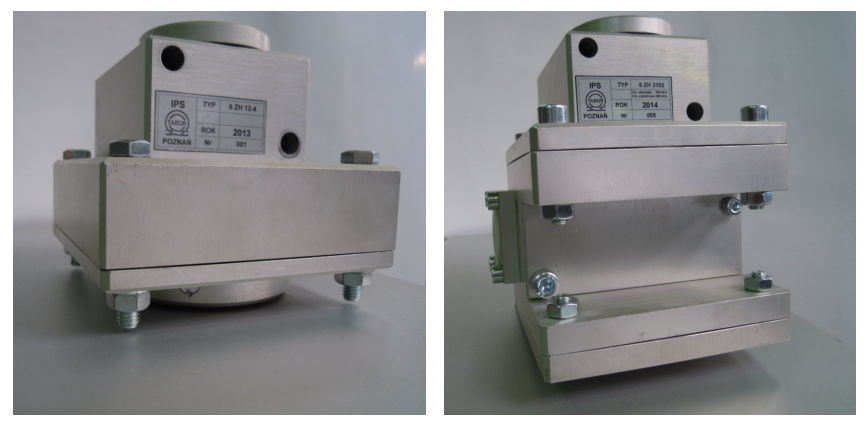

Rys. 1. Przekładnik ciśnienia do Rys. 2. Przekładnik ciśnienia do napełniania cylindrów hamulco- napełniania cylindrów hamulcowych lub przewodu głównego wych o regulowanym przełożeniu. zespołów trakcyjnych

W oparciu m.in. o moduły jakimi są przekładniki ciśnienia, Instytut Pojazdów Szynowych „TABOR” w Poznaniu, opracował i wdrożył zintegrowane systemy hamulcowe dla: zespołów trakcyjnych EN-57, EW60, EN-71 i EN-72 modernizowanych przez Newag Nowy Sącz i ZNTK Mińsk Mazowiecki dla Przewozów Regionalnych, EN-97 nowy pojazd wyprodukowany przez PESA Bydgoszcz dla Warszawskiej Kolei Dojazdowej, lokomotyw ET-22, SM-42, ST-44, ST45, ST-46 dla PKP Cargo i innych prywatnych operatorów [2]. Na rysunkach 3 i 4 przedstawiono wielkość sprzedaży oraz strukturę dostaw pneumatycznych tablic hamulcowych produkcji IPS „TABOR”, na których zamontowane są przekładniki ciśnienia.

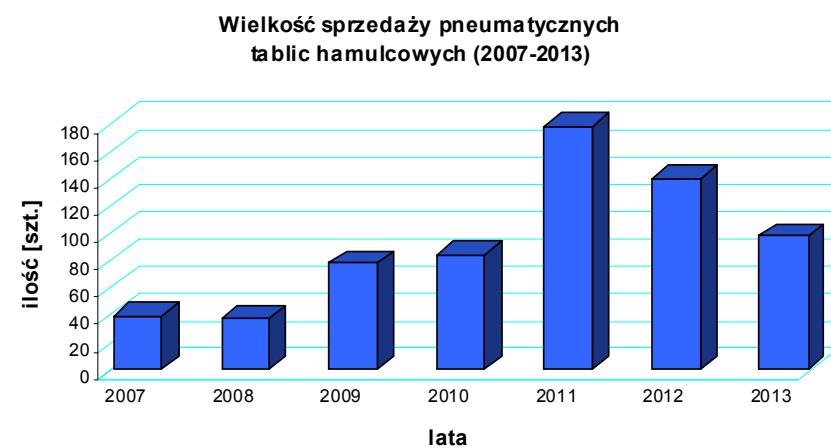

Rys. 3. Wielkość sprzedaży pneumatycznych tablic hamulcowych w latach 2007-2013

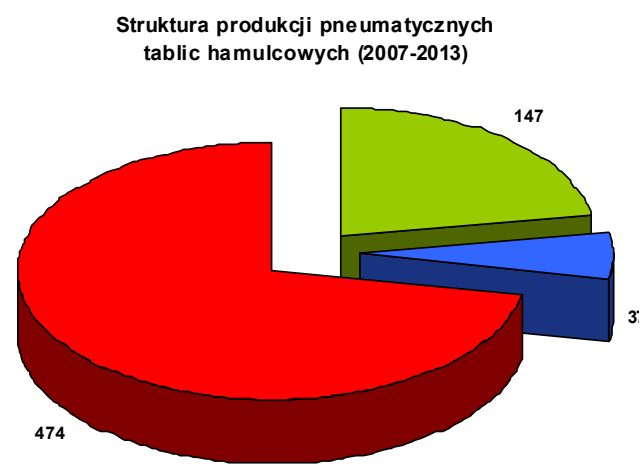

口lokomotywy $\square$ wagony $\square$ ezt

Rys. 4. Struktura produkcji pneumatycznych tablic hamulcowych w latach 2007-2013

\section{OPIS PRZEKLADNIKA CIŚNIENIA CY- LINDRÓW HAMULCOWYCH}

Przekładnik ciśnienia jest to aparat pneumatyczny służący do wzmacniania sygnału pneumatycznego o wymaganym (przez układ sterowania) ciśnieniu w cylindrze (-ach). Przekładniki ciśnienia możemy podzielić na dwie podstawowe grupy:

- sterujące ciśnieniem w przewodzie głównym,

- sterujące ciśnieniem w cylindrach hamulcowych.

Poniżej przedstawiono podział przekładników ciśnienia sterujących ciśnieniem w cylindrach hamulcowych zgodny $\mathrm{z}$ europejską normą $\mathrm{PN}-\mathrm{EN}$ $15611+\mathrm{A} 1$ [3].

1. Jednostopniowy przekładnik ciśnienia typu A przekładnik z jednym stałym przełożeniem, w którym przełożenie to może być mniejsze, równe lub większe niż 1 .

2. Wielostopniowy przekładnik ciśnienia typu B przekładnik ciśnienia $\mathrm{z}$ więcej niż jednym stałym przełożeniem, przy czym przełożenia mogą być mniejsze, równe lub większe niż 1 .

3. Wielostopniowy przekładnik ciśnienia typu B1 - przekładnik, którego przełożenie może ulegać zmianie podczas hamowania.

4. Wielostopniowy przekładnik ciśnienia typu B2 - przekładnik, którego przełożenie nie może ulegać zmianie podczas hamowania.

5. Przekładnik ciśnienia próżny - ładowny, szczególny typ przekładnika wielostopniowego (typu B1 lub B2) tylko z dwoma stopniami, podający ciśnienie wyjściowe $\mathrm{w}$ stanie próżnym lub ładownym, które jest proporcjonalne do ciśnienia wejściowego zależnie od sygnału obciążenia.

6. Przekładnik ciśnienia typu C o zmiennym sygnale obciążenia - przekładnik ciśnienia $\mathrm{z}$ ciągłą zmianą przełożenia, gdzie sygnał obciążenia jest użyty w celu zmiany tego przełożenia.

7. Wielostopniowy przekładnik ciśnienia typu $\mathrm{C} 1$ o zmiennym sygnale obciążenia- wielostopniowy przekładnik ciśnienia $\mathrm{z}$ ciaggłą zmianą przełożenia, gdzie sygnał obciążenia jest użyty w celu zmiany tego przełożenia.

8. Przekładnik ciśnienia typu $\mathrm{D}$ z wieloma sygnałami wejścia - przekładnik ciśnienia (typu A, B lub C) $\mathrm{z}$ dwoma (lub więcej) sygnałami wejściowymi, kontrolującymi pojedyncze ciśnienie wyjścia.

9. Przekładnik ciśnienia typu E ze zmiennym sygnałem obciążenia i z załamaną charakterystyką - przekładnik ciśnienia o zmiennym sygnale obciążenia (typu C) ze szczególna, nieliniową charakterystyka, która pojawia się automatycznie podczas eksploatacji kiedy pojazd jest hamowany z odpowiednio większa 
skutecznością hamowania.

Na rys. 5. przedstawiono miejsce przekładnika ciśnienia w układzie hamulcowym pojazdu szynowego. Może on być zainstalowany w różnej odległości od zaworu rozrządczego na oddzielnym wsporniku lub wspólnym wsporniku z zaworem rozrządczym (tzw. układ kompaktowy albo zespół hamulcowy). Istnieją też konstrukcje, w których przekładnik przymocowany jest wprost do zaworu rozrządczego. Jednak w tym opracowaniu zostaną przedstawione przekładniki ciśnienia, które są zamontowane jako aparaty modułowe na hamulcowych tablicach pneumatycznych pojazdów szynowych, produkowane przez Instytut Pojazdów Szynowych „TABOR”.

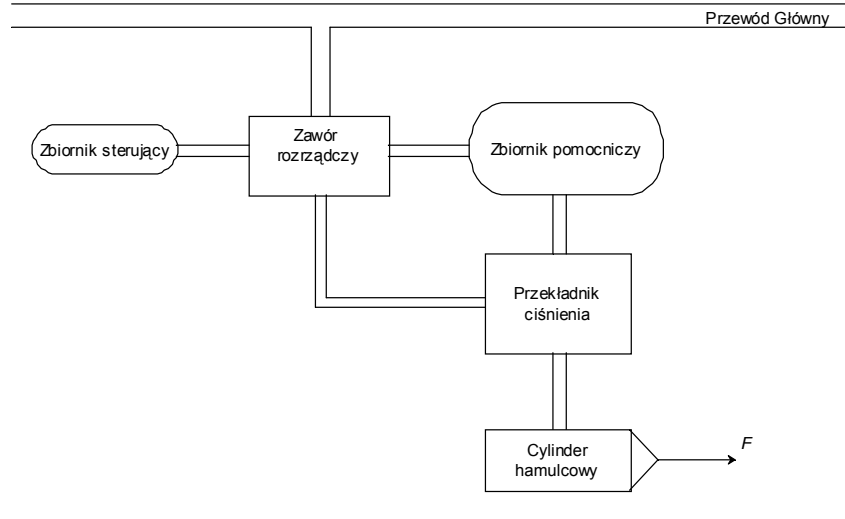

Rys. 5. Miejsce przekładnika ciśnienia w układzie hamulcowym pojazdu szynowego

W konstrukcji przekładnika zastosowano szereg rozwiązań opartych na tłokach przenoszących odpowiednie siły i ciśnienia, uszczelnionych membranami, zaworkach $\mathrm{z}$ gumowym pierścieniem uszczelniającym typu O-ring i typu U oraz sprężynach. Przewidziano także bardzo szeroki zakres regulacji parametrów w celu dopasowania charakterystyki przekładnika ciśnienia do zróżnicowanych potrzeb pojazdów szynowych.

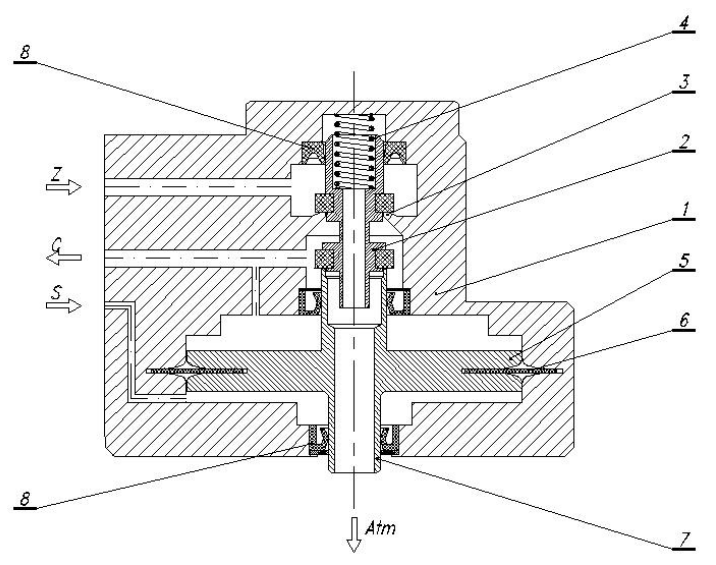

Rys. 6. Schemat działania jednostopniowego przekładnika ciśnienia produkcji IPS „TABOR”

$Z$ - powietrze zasilajace, $C$ - cylinder, $S$ - sygnat sterujacy, 1 korpus przektadnika, 2-zaworek napetniajacy, 3 - siedzisko zaworka, 4-sprężyna, 5-tłok, 6-membrana, 7-trzon drażony, 8 - pierścień uszczelniajacy
Główny element przekładnika ciśnienia składa się z wyprofilowanego trzonu drążonego (8) połączonego z tłokami (5) i membranami (6). Porusza się on w korpusie (1) w górę lub w dół zależnie od różnicy ciśnień występującej po dwóch stronach membrany. Do każdego przekładnika stale jest dostarczane powietrze zasilające (Z) ze zbiorników pomocniczych. Gdy zawór rozrządczy wygeneruje sygnał sterujący (S) do komory pod dolnym tłokiem dochodzi do przesunięcia $\mathrm{w}$ górę trzonu i otwarcia zaworka (2), co pozwala na przepływ się powietrza zasilającego na stronę wyjściową przekładnika (C) do pojemności cylindra hamulcowego. W sytuacji odwrotnej, gdy maleje sygnał sterujący (S), zaworek zamyka dopływ z zasilania $(Z)$, a powietrze znajdujące się po stronie wyjściowej (C) przekładnika uchodzi z cylindra do atmosfery poprzez trzon drążony.

\section{WYMAGANIA DOTYCZĄCE DZIALANIA PRZEKLADNIKA CIŚNIENIA}

Histereza - zjawisko histerezy przedstawia się najczęściej na wykresie dwóch zależnych od siebie wielkości w postaci pętli histerezy (rys. 7)

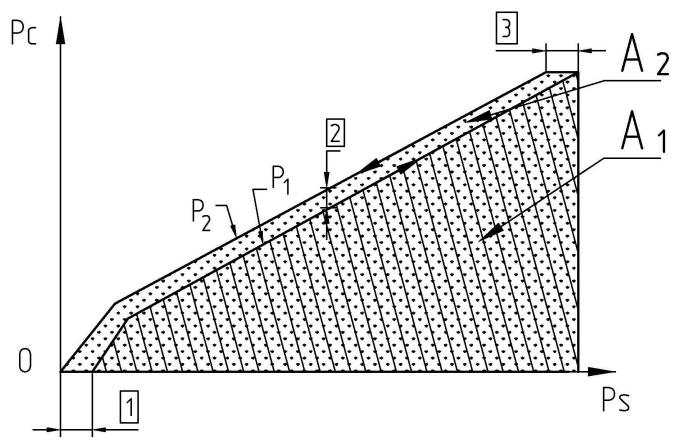

Rys. 7. Wykres obrazujący histerezę i czułość przekładnika ciśnienia.

1- czułość inicjacyjna, 2 - histereza, 3 - czułość odwrócona, $p_{s}$ - ciśnienie wejściowe, $p_{c}$ - ciśnienie wyjściowe. [1]

Pod pojęciem histerezy przekładnika ciśnienia rozumiemy różnicę ciśnienia cylindrowego (wyjściowego) dla tej samej wartości ciśnienia sterującego (wejściowego), przy czym raz ciśnienie sterujące wzrasta do zadanej wartości, a drugim razem spada do wartości zadanej. Tak określona histereza przekładnika ciśnienia jest wielkością wyrażoną w $\mathrm{kPa}$ (1).

gdzie:

$$
H=P_{2}-P_{1}
$$

$P_{l}$ - ciśnienie wyjściowe przy wzroście ciśnienia wejściowego,

$P_{2}$ - ciśnienie wyjściowe przy spadku ciśnienia wejściowego.

Można również ocenić wielkość histerezy (strat) przekładnika bezwymiarową wielkością zwaną sprawnością przekładnika ciśnienia (2). 


$$
\eta=\frac{A_{1}}{A_{2}}
$$

gdzie:

$A_{1}$ - pole powierzchni pod krzywą obrazująca wzrost ciśnienia,

$A_{2}$ - pole powierzchni pod krzywą obrazującą spadek ciśnienia.

Czułość - w przypadku przekładnika ciśnienia jest to odpowiedź ciśnienia cylindrowego (wyjściowego) na zmianę ciśnienia sterującego (wejściowego). Zgodnie z normą PN - EN 15611+A1 rozróżniamy czułość:

- inicjacyjną, polegającą na tym, że zmiana ciśnienia wejściowego, począwszy od $0 \mathrm{kPa}$, powoduje, że ciśnienie wyjściowe zacznie wzrastać,

- powrotną, występująca gdy ciśnienie wejściowe zmienia swój kierunek $\mathrm{z}$ rosnącego do malejącego.

Zgodnie z normą PN - EN 15611+A1, dopuszczalna czułość dla przekładników ciśnienia wynosi [1]:

1. dla przekładnika o przełożeniu 1 lub większym czułość musi wynosić $\leq 10 \mathrm{kPa}$.

2. dla przekładnika o przełożeniu mniejszym niż 1 czułość jest wyrażona $\mathrm{w}$ stopniach hamowania i luzowania. Minimum 5 stopni zmiany ciśnienia wyjściowego musi zostać osiągniętych pomiędzy inicjacyjnym a maksymalnym ciśnieniem wejściowym.

3. czułość inicjacyjna dla wszystkich przekładników ciśnienia musi wynosić $\leq 30 \mathrm{kPa}$. Wzrost ciśnienia wejściowego do wartości 30 $\mathrm{kPa}$ powinien spowodować wzrost ciśnienia wyjściowego do wartości $\geq 10 \mathrm{kPa}$.

4. czułość odwrócona, dla przekładnika ciśnienia o przełożeniu 1 lub większym, musi wynosić $\leq 20 \mathrm{kPa}$.

5. czułość odwrócona, dla przekładnika ciśnienia o przełożeniu pomiędzy 0,5 a 1 musi wynosić $\leq 40 \mathrm{kPa}$.

Dla przekładników ciśnienia o przełożeniu mniejszym niż 0,5 nie ma określonych wymagań co do czułości.

\section{BADANIA STANOWISKOWE}

Stanowisko do badań przekładników ciśnienia zostało utworzone $\mathrm{w}$ oparciu i przy wykorzystaniu ogólnego stanowiska kontrolno pomiarowego SKP znajdującego się w Dziale Kontroli Jakości Instytutu Pojazdów Szynowych „TABOR”. Stanowisko SKP [rys. 8.] służy do odbioru zarówno skomplikowanych układów hamulcowych takich jak kontenery i tablice pneumatyczne oraz pojedynczych aparatów pneumatycznych.

Całość układu jest zasilana sprężonym powietrzem wytwarzanym przez sprężarkę śrubową. W skład stanowiska wchodzą zespoły zbiorników na sprężone powietrze, reduktorów ciśnienia, zaworów odcinających, elektrozaworów, manometrów i różnego rodzaju przyłączy pneumatycznych. Na każdym przyrządzie do pomiaru ciśnienia zabudowany jest przetwornik ciśnienia, który przy pomocy konwertera sygnałów oraz odpowiednio oprogramowanego komputera pozwala na wizualizację i rejestrację przebiegów ciśnień, będących parametrami pracy danego układu hamulcowego, w funkcji czasu.

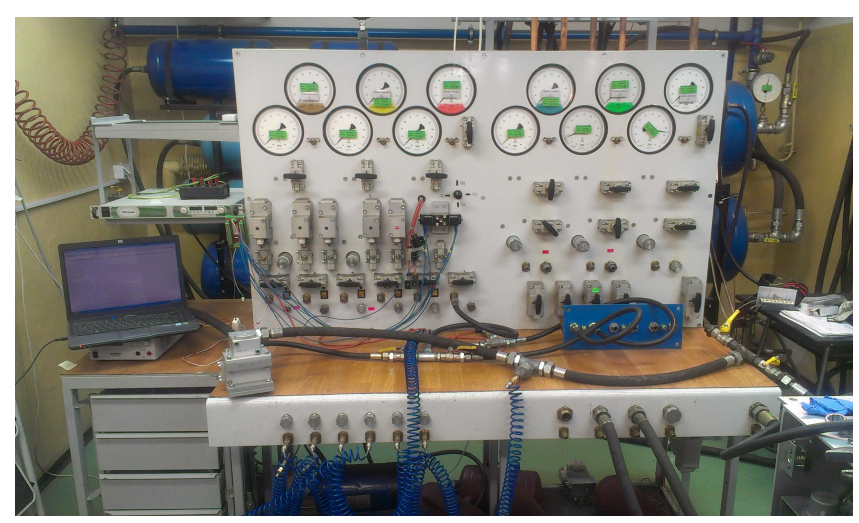

Rys. 8. Widok ogólny stanowiska kontrolno pomiarowego SKP

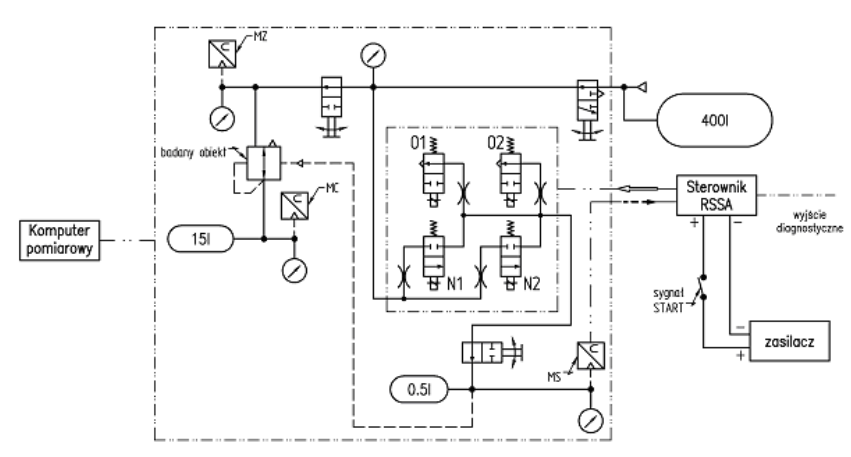

Rys. 9. Schemat stanowiska do badań przekładników ciśnienia.

$\mathrm{Na}$ stanowisku przedstawionym na rysunku 8 dokonano badań przekładnika ciśnienia typu 6ZH 124 oraz 6ZH 31 (rys.1 i 2). Badanie polegało na przeanalizowaniu przebiegów ciśnień cylindrowych uzyskanych podczas próby hamowania i luzowania, zgodnie z opracowanym algorytmem sterowania ciśnieniem i porównaniu ich $\mathrm{z}$ wymaganiami dotyczącymi działania przekładnika ciśnienia. Pomiarów dokonano dla 8 sprężyn (rys. 6, poz. 4) o różnej charakterystyce. Sprężyny dobrano w odniesieniu do nominalnie stosowanej. Na rysunku 10 znajduje się przebieg całej próby dla przekładnika ciśnienia typu $6 Z$ ZH 12-4. Próba składa się $\mathrm{z}$ hamowania pełnego i luzowania po takim hamowaniu, hamowania i luzowania stopniowego (wzrost i spadek ciśnienia co 20 $\mathrm{kPa}$ ), próby czułości dla niskiego oraz wysokiego ciśnienia (wzrost i spadek ciśnienia co $5 \mathrm{kPa}$ ). Natomiast na rysunku 11 znajduje się podobny przebieg ciśnień, z tą różnicą że próba dotyczy drugiego typu przekładnika ciśnienia czyli 6ZH 31 oraz przebiegi ciśnień cylindrowych zostały zarejestrowane dla 
dwóch sprężyn o różnych charakterystykach - bardzo słabej i bardzo mocnej (tab. 1).

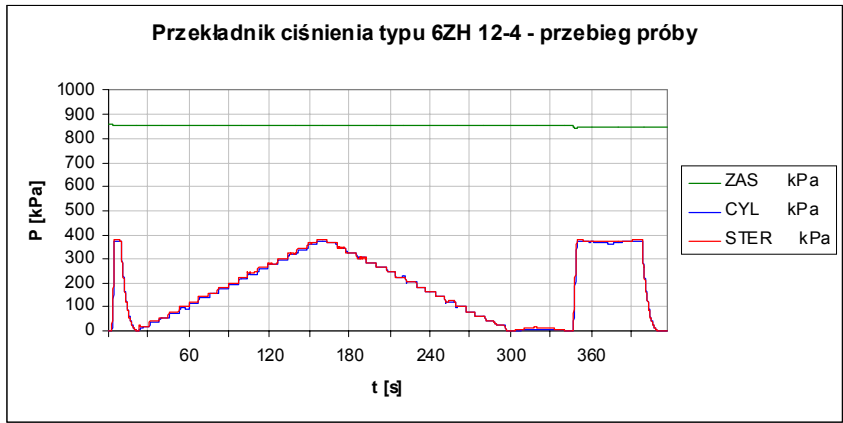

Rys. 10. Przebieg ciśnień cylindrowych dla całej próby zgodnie z algorytmem sterowania ciśnieniem.

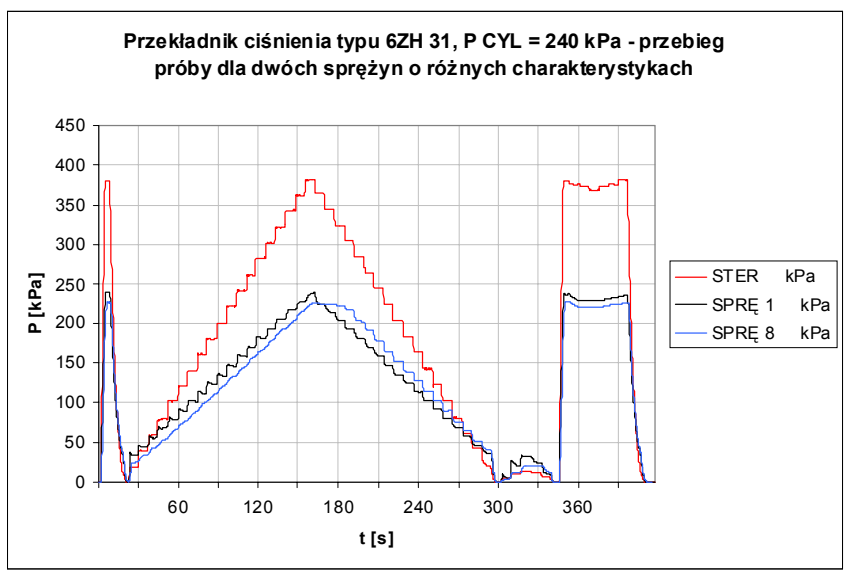

Rys. 11. Przebieg ciśnień cylindrowych przekładnika typu 6ZH 31 dla dwóch sprężyn o różnych charakterystykach.

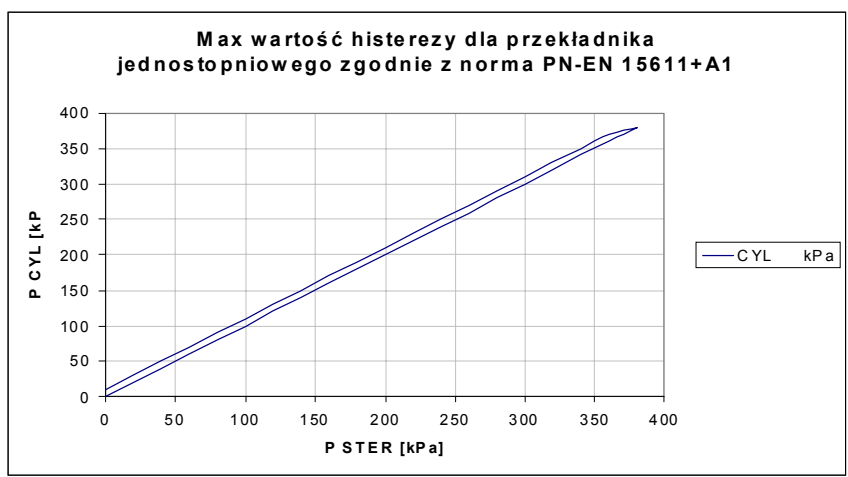

Rys 12. Wymagana wartość histerezy dla jednostopniowego przekładnika ciśnienia.

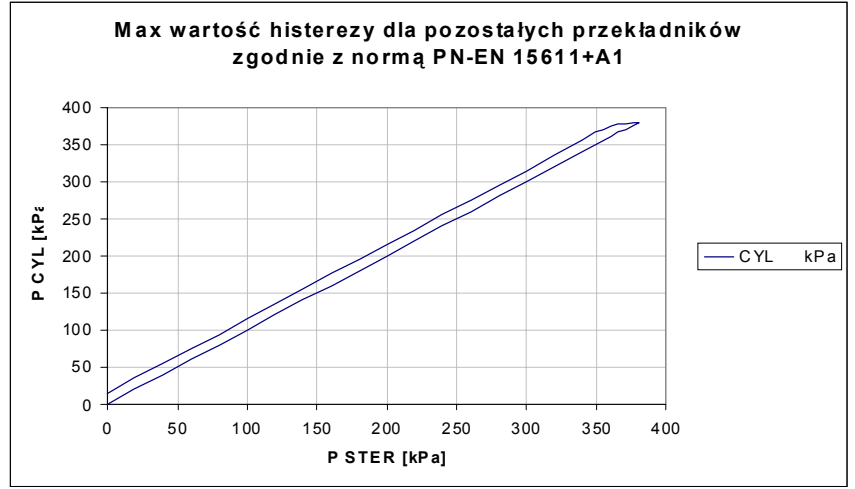

Rys. 13. Wymagana wartość histerezy dla przekładników ciśnienia innych niż jednostopniowe.

Zgodnie ze wzorami (1) i (2) wyznaczono następujące dopuszczalne wartości histerezy w ujęciu liczbowym:

- jednostopniowe przekładniki ciśnienia (rys. 12):

$$
\begin{gathered}
H=10 \mathrm{kPa} \\
\eta_{(\mathrm{w})}=0,9512
\end{gathered}
$$

- pozostałe przekładniki ciśnienia (rys. 13):

$$
\begin{gathered}
H=15 \mathrm{kPa} \\
\eta_{(w)}=0,9286
\end{gathered}
$$

Z uwagi na fakt, że przebieg pętli histerezy dla hamowania i luzowania stopniowego w rzeczywistości odbiega od przebiegu wzorcowego przedstawionego na rysunkach 12 i 13, niemożliwe jest jednoznaczne określenie wartości histerezy w $\mathrm{kPa}$. W związku z tym postanowiono określić histerezę przekładnika ciśnienia tylko w oparciu o wielkość bezwymiarową zgodnie z rys. 7 .

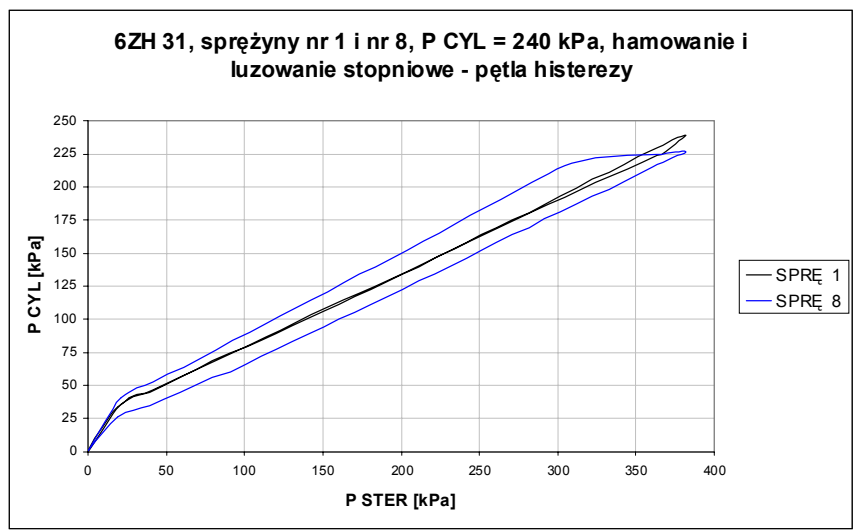

Rys. 14. Pętle histerezy dla sprężyny nr 1 i sprężyny nr 8.

Tabela 1. Parametry sprężyn wykorzystanych do badań przekładników ciśnienia

\begin{tabular}{|c|c|c|c|c|c|c|c|c|c|}
\hline Nr sprężyny & $\mathbf{P 1}[\mathbf{N}]$ & $\mathbf{P} 2[\mathbf{N}]$ & $\mathbf{d}[\mathbf{m m}]$ & $\mathbf{D}[\mathbf{m m}]$ & $\mathbf{L}_{\mathbf{0}}[\mathbf{m m}]$ & $\mathbf{L}_{\mathbf{b} \mathbf{1}}[\mathbf{m m}]$ & $\mathbf{z}$ & $\mathbf{z}_{\mathbf{c}}$ & $\mathbf{C}[\mathbf{N} / \mathbf{m m}]$ \\
\hline 1 & 2,2 & 5,1 & 0,7 & 9,3 & 23,0 & 4,2 & 6,0 & 4,0 & 0,73 \\
\hline nominalna & 12,9 & 30,1 & 1,2 & 9,3 & 23,0 & 12,6 & 8,0 & 6,0 & 4,30 \\
\hline 8 & 61,8 & 78,1 & 1,3 & 9,3 & 35,2 & 13,7 & 10,5 & 8,5 & 4,07 \\
\hline
\end{tabular}

Gdzie:

P1 [N] - napięcie wstępne sprężyny

$P 2[N]$ - max siła napięcia sprężyny

$d[\mathrm{~mm}]$ - średnica drutu

$z$-całkowita liczba zwojów

$z_{c}-$ liczba zwojów czynnych

$D[\mathrm{~mm}]$ - średnica sprężyny

$C[\mathrm{~N} / \mathrm{mm}]$ - stała sprężyny (sztywność)

$L_{0}[\mathrm{~mm}]-$ dtugość sprężyny 
Obliczając stosunek pól powierzchni pod krzywą obrazującą napełnianie cylindra hamulcowego do pól powierzchni pod krzywą obrazująca luzowanie cylindra hamulcowego zgodnie ze wzorem (2) otrzymano następujące wyniki:

- dla sprężyny nr $1 \quad \boldsymbol{\eta}=\mathbf{0 , 9 9 0 3}$

- dla sprężyny nr $8 \boldsymbol{\eta}=\mathbf{0 , 8 4 0 4}$

Porównując otrzymane wyniki z wymaganymi parametrami możemy zauważyć, że sprężyna $\mathrm{nr} 1$ spełnia wymagania dotyczące wielkości histerezy ( $\boldsymbol{\eta}$ $\left.>\boldsymbol{\eta}_{(\mathrm{w})}\right)$, natomiast sprężyna $\mathrm{nr} 8$ tych wymagań nie spełnia $\left(\boldsymbol{\eta}<\boldsymbol{\eta}_{(\mathbf{w})}\right)$.

\section{PODSUMOWANIE}

W pracy przedstawiono istote $\mathrm{i}$ zastosowanie przekładników ciśnienia w układach hamulcowych pojazdów szynowych. Przekładniki są modułami zapewniającymi prawidłowe działanie hamulca $\mathrm{w}$ pojazdach szynowych. Dlatego ich poprawne funkcjonowanie zapewnia skuteczne hamowanie pociagu a przez to zapewnienie bezpieczeństwa pasażerom i ładunkom.
Zapoczątkowane badania przekładników ciśnienia związane są z opracowaniem metody oceny ich stanu technicznego. Przedstawiono wyniki badań sprężyny przekładnika, oraz możliwości wykorzystania pola histerezy jako parametru pozwalającego ocenić jego stan techniczny. Wartość histerezy oceniano bezwymiarową wielkością zwaną sprawnością przekładnika, analizując przebiegi ciśnień podczas hamowania i luzowania stopniowego realizowanego przez przekładnik ciśnienia zgodnie $\mathrm{z}$ normą PN-EN 15611+A1 [3]. Przeprowadzone badania wykazały zależność między siłą zastosowanej sprężyny a wartością histerezy działania przekładnika ciśnienia.

W dalszych pracach realizowane będą badania pozostałych elementów przekładnika ciśnienia w celu pełnej diagnostyki i lokalizacji niezdatności.

\section{LITERATURA}

[1] Maluśkiewicz M., Goliwas D.: Analiza systemów diagnozowania stanu układów sterowania hamulcami pojazdów szynowych. OR-9759. Opracowanie wewnętrzne IPS ,TABOR”. Wrzesień 2010

[2] Kaluba M., Goliwas D.: Modułowy system sterowania hamulcami pojazdów trakcyjnych . Pojazdy Szynowe 4/2012

[3] PN-EN 15611+A1: 2011: Kolejnictwo - Hamowanie Przekładniki ciśnienia. 